\title{
Comparative Quality Assessment of Three Different Marketed Brands of Indian Polyherbal Formulation - Triphala Churna
}

\author{
Princy Agarwal ${ }^{1 *}$, Anju Goyal ${ }^{2}$ and Rajat Vaishnav ${ }^{3}$ \\ ${ }^{1}$ M Pharma Research Scholar, Department of Quality Assurance, Bhupal Nobles Institute of Pharmaceutical Sciences, India \\ ${ }^{2}$ Professor and HOD, Department of Quality Assurance, Bhupal Nobles Institute of Pharmaceutical Sciences, India \\ ${ }^{3}$ Assistant Professor, Department of Quality Assurance, Bhupal Nobles Institute of Pharmaceutical Sciences, India
}

Received: May 31, 2018; Published: June 15, 2018

*Corresponding author: Princy Agarwal, M.Pharma Research Scholar, Department of Quality Assurance, Bhupal Nobles Institute of Pharmaceutical Sciences, Sevashram Road, Udaipur, Rajasthan, India

\section{Abstract}

Triphala Churna is a polyherbal formulation widely used in the traditional Indian system of medicine. It is an anti-oxidant rich formulation and possesses diverse beneficial properties.

Objective: The present study was designed to evaluate quality profile of Indian polyherbal formulation Triphala Churna. The study was proposed to assess the variation in quality specifications and comparing them with the standard values prescribed within the Ayurvedic and Indian Pharmacopoeia so that industry and regulatory agencies can be made aware about the defects if any, and recommendations may be proposed about the quality and consistency status of the products available in the market.

Methods: Three different marketed formulations of Triphala Churna were assessed comparatively for their organoleptic, physicochemical and phytochemical properties as per the methods prescribed in Pharmacopoeias.

Results: The data analysis revealed that all the parameters of three brands of Triphala Churna had approximately similar values with some significant variations in a few parameters and were compatible with the standard values mentioned in the Pharmacopoeias.

Conclusion: Therefore the present investigation reveals that there is a need to make more stringent quality control parameters in order to reduce variation among different Ayurvedic preparations.

Keywords: Quality Evaluation; Triphala Churna; Pharmaceutical Analysis; Physico-Chemical Analysis; Phytochemical Analysis; Heavy Metal Analysis

Abbreviations: API: Ayurvedic Pharmacopoeia of India; IP: Indian Pharmacopoeia; Pb: Lead; Cd: Cadmium

\section{Introduction}

Ayurveda is a system of herbal medicines accredited throughout the world and includes various Ayurvedic formulations such as Asava, Arishta, Ghruta, Taila, Churna, Vati, Gutika, Kwatha and much more. A variety of medicinal herbs has been used in the Ayurvedic medicine system since ancient times in both developed and developing countries [1]. Evaluation of the quality of herbal formulations is important to justify their acceptability and safety. One of the main problems faced by Ayurveda is the lack of unique quality control parameters for herbal medicines and their formulations. The standardization of herbal formulations is essential for assessing the quality of drugs. It is based on the concentration of its active ingredients, physical, chemical, phytochemical and in vitro, in vivo parameters [2].

Triphala (Sanskrit; tri $=$ three and phala = fruits) is a wellrecognized and revered polyherbal medicine consisting of dried fruits of the three plant species Emblica officinalis (Family Euphorbiaceae), Terminalia bellerica(Family Combretaceae), and Terminalia chebula (Family Combretaceae) that are native to the Indian subcontinent. It is classified as a tridoshic rasayana in Ayurvedic medicine as it promotes longevity and rejuvenation in patients of all constitutions and ages. The formula consists of the fruits Amalaki or the Indian Gooseberry, Bibhitaki, and Haritaki of 
the three plants generally in equal proportions (1:1:1) and has been used in traditional medicine in India for over 1000 years [3]. It has various applications in medical field like laxative, eye rejuvenator, antiinflammatory, antiviral and so on. It is also effective in headache, dyspepsia, ascites, and leucorrhea, also used as a blood purifier and possess anti- inflammatory, analgesic, antiarthritic, hypoglycemic and anti -aging properties. Triphala is claimed to have antiviral and antibacterial effect [4-13].

\section{Materials and Methods \\ Procurement of Samples}

The following marketed Triphala Churna preparations were used in the present study. Brand A (Batch No. AL 1700), Brand B (Batch No. E-1701), Brand C (Batch No. \#A-TPC015). All brands of the Triphala Churna were procured from the local market from the registered Ayurvedic Pharmacy.

\section{Organoleptic Evaluation}

All the organoleptic properties viz. color, odor, taste, and texture of the drug to touch were performed as per standard procedure and noted down.

\section{Pharmaceutical Evaluation}

Pharmaceutical parameters like Bulk density, Tapped density, Carr's Index, Hausner's Ratio and Angle of repose were determined as per standard protocols.

Determination of Bulk Density and Tapped Density: Bulk density is defined as the mass of many particles of the material divided by the total volume they occupy. The total volume includes particle volume, inter-particle void volume and internal pore volume. Tapped density is the term used to describe the bulk density of a powder (or granular solid) after consolidation/compression prescribed in terms of "tapping" the container of powder a measured number of times, usually from a predetermined height.

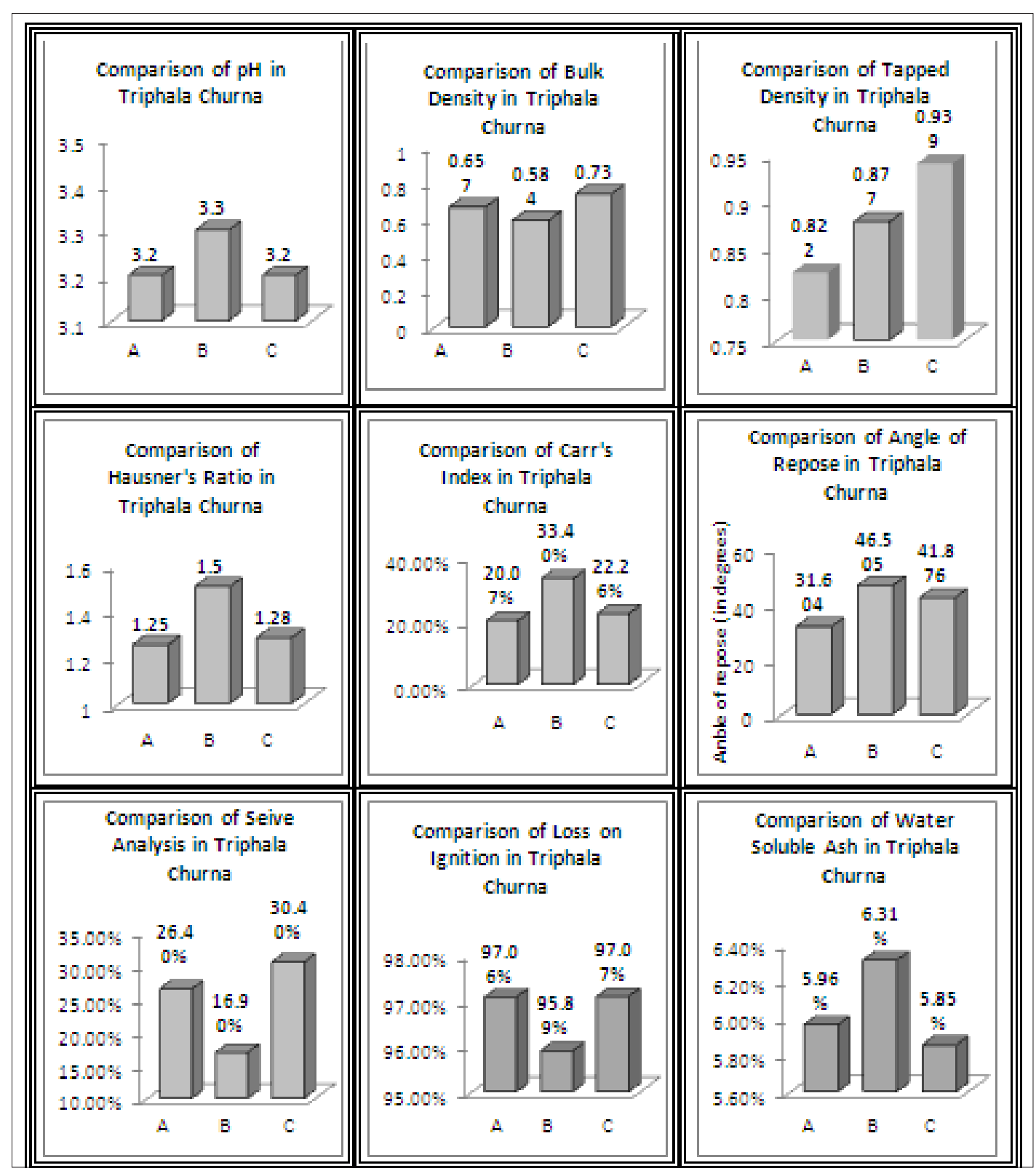



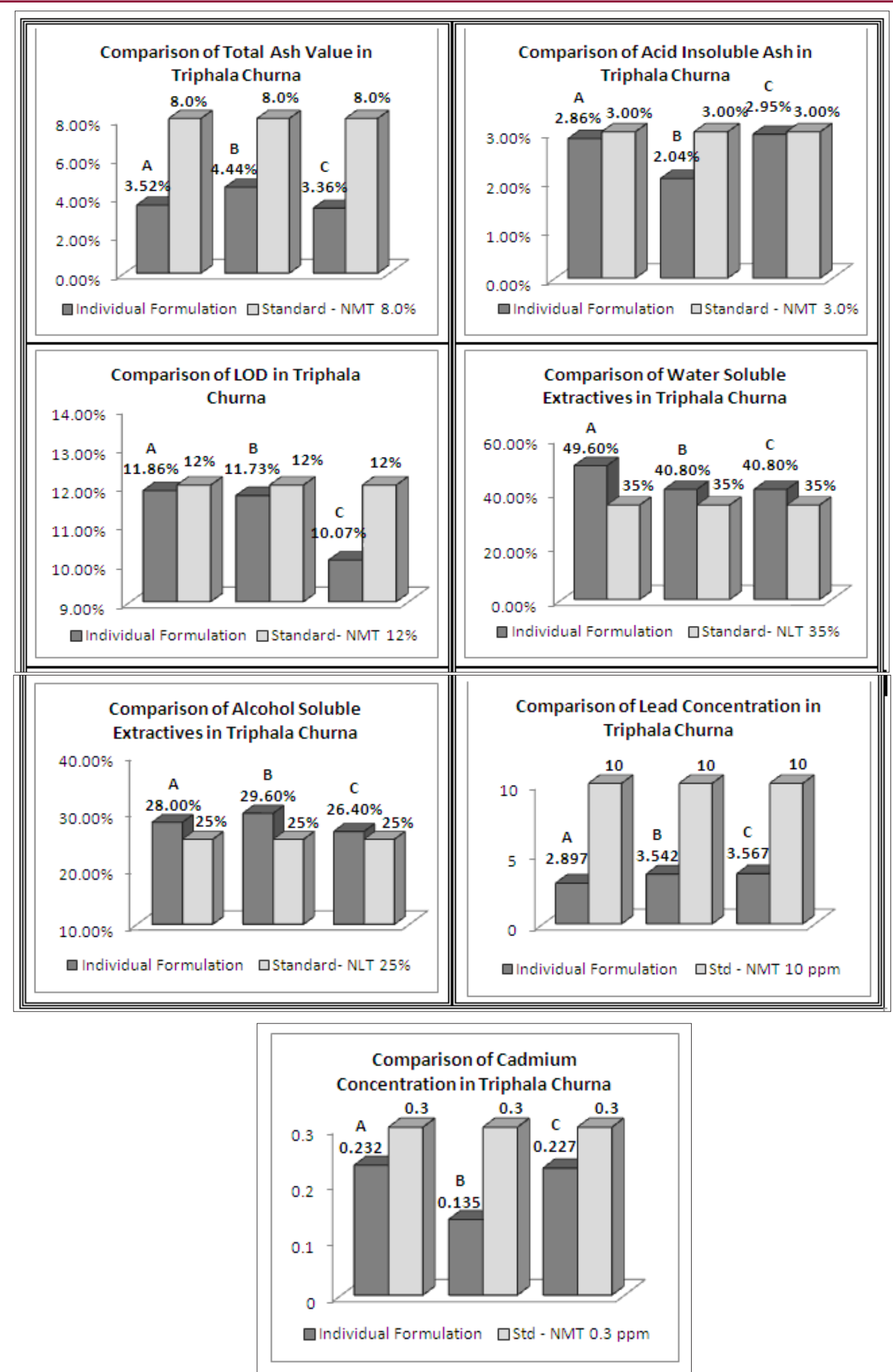

Figure1: Graphs for various Pharmaceutical and Physico-chemical parameters of different brands of Triphala Churna

The term bulk density refers to a measure used to describe a packing of particles or granules and the term Tapped density refers to the true density of the particles or granules (Figure 1).
Formula for calculation:

$$
\text { Bulk Density }=\frac{\text { Weight of power taken }}{\text { Bulk Volume of powder }}=\frac{10}{\pi r^{2} h_{b}}
$$




$$
\text { Tapped Density }=\frac{\text { Weight of powder taken }}{\text { Tapped Volume of powder }}=\frac{10}{\pi r^{2} h_{t}}
$$

Where,

$\pi r^{2} \mathrm{~h}=$ Volume of Graduated Cylinder

$\mathrm{h}_{\mathrm{b}}=$ Bulk height of powder

$h_{t}=$ Tapped height of powder

Determination of Carr's Compressibility Index: The Carr index is an indication of the compressibility of a powder. It is another indirect method of measuring the powder flow from bulk and tapped density.

Formula for calculation:

$$
\text { Carr's Index }(\%)=\frac{\text { Tapped Density }- \text { Bulk Density }}{\text { Tapped Density }} \times 100
$$

Determination of Hausner's Ratio: Hausner's ratio is related to inter-particle friction and as such can be used to predict the powder flow properties.

Formula for calculation:

$$
\text { Hausner's Ratio }=\frac{\text { Tapped Density }}{\text { Bulk Density }}
$$

Determination of Angle of Repose: The angle of repose is a parameter used to estimate the flowability of a powder. It is defined as the maximum angle possible between the surface of the pile of powder and the horizontal plane. Powders with low angles of repose will flow freely and powders with high angles of repose will flow poorly.

Formula for calculation:

Where,

$$
\tan \theta=\frac{h}{r}
$$

$$
\begin{aligned}
& \theta=\text { Angle of repose } \\
& h=\text { Height of pile } \\
& r=\text { radius of the base of pile tan vv }
\end{aligned}
$$

\section{Physico-Chemical Evaluation}

Physicochemical parameters like foreign matter, moisture content (Loss on Drying), pH, total ash, acid Insoluble ash, water-soluble extractive, alcohol soluble extractive values of all three samples were determined as per standard protocols. All the procedures are described as follows:

Determination of Foreign Matter: $100 \mathrm{~g}$ of sample was taken and spread in a thin layer on a suitable platform and was examined in daylight with unaided eye (or using $6 \mathrm{x}$ or 10x magnifying glass) and the foreign matter was separated and weighed. The percentage of foreign matter was calculated with reference to the drug sample.

Standard: The sample should not contain more than $2 \%$ of foreign matter, unless otherwise specified in individual monograph.
Determination of Moisture Content/ Loss on Drying (LOD): An accurately weighed $5 \mathrm{~g}$ of polyherbal formulation powder was taken in a tarred evaporating dish. The crude drug was then heated at $105{ }^{\circ} \mathrm{C}$ in an oven for 3 hours. The drying and weighing was continued at half an hour interval until difference between two successive weighing corresponded to, not more than 0.25 per cent. Percentage moisture content of the sample was calculated with reference to the air dried powdered drug material.

Formula for calculation:

$$
\% L O D=\frac{w_{2}-w_{3}}{w_{3}-w_{1}} \times 100 \%
$$

Where,

$$
\begin{aligned}
& \mathrm{W}_{1}=\text { weight of container }(\mathrm{g}) \\
& \mathrm{W}_{2}=\text { weight of container }+ \text { wet sample }(\mathrm{g}) \\
& \mathrm{W}_{3}=\text { weight of container }+ \text { dried sample }(\mathrm{g}) \\
& \mathrm{W}_{2}-\mathrm{W}_{3}=\text { weight of moisture } \\
& \mathrm{W}_{3}-\mathrm{W}_{1}=\text { weight of dried sample }
\end{aligned}
$$

\section{Determination of Loss on Ignition (LOI)}

An accurately weighed $5 \mathrm{~g}$ of polyherbal formulation powder was taken in a previously ignited and tared silica crucible and was heated in the oven at $105{ }^{\circ} \mathrm{C}$ overnight (or the previously dried sample can also be used). The crucible was cooled and reweighed. The crucible was then placed into the furnace tray and was ignited in the Muffle Furnace at $500{ }^{\circ} \mathrm{C}$ for about $4 \mathrm{hrs}$. The sample was then cooled in a dessicator for $30 \mathrm{~min}$ and reweighed with the ash in it $\left(\mathrm{W}_{\mathrm{A}}\right)$. The observations were noted.

Formula for calculation:

Where,

$$
\% L O I=\frac{w_{s}-w_{a}}{w_{s}-w_{c}} \times 100 \%
$$

$\mathrm{W}_{\mathrm{C}}=$ weight of crucible $(\mathrm{g})$

$\mathrm{W}_{\mathrm{S}}=$ weight of sample $(\mathrm{g})$

$\mathrm{W}_{\mathrm{A}}=$ weight of ash $(\mathrm{g})$

Determination of Total Ash: An accurately weighed 3g of the sample was taken in a previously ignited and tared silica dish/ crucible. The material was evenly spread and ignited in a Muffle Furnace by gradually increasing the temperature to not more than $450{ }^{\circ} \mathrm{C}-600{ }^{\circ} \mathrm{C}$ till the carbon free ash was not obtained. The total ash value was calculated with reference to the air-dried powdered drug material.

Formula for calculation:

$$
\% \text { Total Ash }=\frac{\text { Weight of } A s h}{\text { Weight of sample taken }} \times 100 \%
$$

Determination of Acid Insoluble Ash: Ash above obtained, was boiled for $5 \mathrm{~min}$ with $25 \mathrm{ml}$ of $1 \mathrm{M}$ Hydrochloric acid and filtered using an ash less filter paper. Insoluble matter retained on filter paper was washed with hot water and filter paper was 
burnt to a constant weight in a muffle furnace. The percentage of acid insoluble ash was calculated with reference to the air-dried powdered drug material.

Formula for calculation:

$$
\% \text { of acid-Insoluble } A s h=\frac{\text { Weight of acid insoluble residue }}{\text { Weight of sample taken }} \times 100 \%
$$

Determination of Water Soluble Ash: $1 \mathrm{~g}$ of ash obtained in total ash experiment was boiled for $5 \mathrm{~min}$ with $25 \mathrm{ml}$ water and insoluble matter collected on an ashless filter paper which was then washed with hot water and ignited for $15 \mathrm{~min}$ at a temperature not exceeding $450{ }^{\circ} \mathrm{C}$ in a muffle furnace. Difference in weight of ash and weight of insoluble matter was determined as difference represents the value. The percentage of water insoluble ash was calculated with reference to the air-dried powdered drug material.

Formula for calculation:

$$
\% \text { of water soluble } A s h=\frac{\text { Weight of water soluble residue }}{\text { Weight of sample taken }} \times 100 \%
$$

\section{Determination of Extractive Values}

a. Determination of Alcohol Soluble Extractives: 5gm of churna was accurately weighed and placed inside a glass stoppered conical flask. It was then macerated with $100 \mathrm{ml}$ of ethanol. The flask was shaked frequently during the first 6 hours and was kept aside without disturbing for 18 hours. It was then filtered and about $25 \mathrm{ml}$ of filtrate was transferred into a tared flat-bottomed shallow dish and was evaporated to dryness on a water bath. It was then dried to $105^{\circ} \mathrm{C}$ for 6 hours, cooled and finally weighed. The percentage of Alcohol Soluble extractives was calculated with reference to the air-dried powdered drug material.

Formula for calculation:

$$
\% \text { of alcohol soluble Extractive }=\frac{\text { Weight of residue } \times 100 \times 100}{25 \times \text { Weight of sample taken }} \%
$$

Table 2: Preliminary Phytochemical Tests for Plant Extracts b. Determination of Water Soluble Extractives: Proceed as directed for determination of Alcohol-Soluble Extractive, using chloroform water $(2.5 \mathrm{ml}$ chloroform in purified water to produce $1000 \mathrm{ml}$ ) instead of ethanol.

Determination of $\mathbf{p H}$ Value: The powder sample of triphala churna was weighed to about $5 \mathrm{~g}$ and immersed in $100 \mathrm{ml}$ of water in a beaker. The beaker was closed with aluminum foil and left behind for 24 hours in room temperature. Later the supernatant solution was decanted into another beaker and the $\mathrm{pH}$ of the formulation was determined using a calibrated digital $\mathrm{pH}$ meter.

\section{Phytochemical Evaluation}

The aqueous and alcoholic extracts of the respective formulations were prepared and were subjected to preliminary phytochemical screening. These tests reveal the presence of various bioactive secondary metabolites which might be responsible for their medicinal attributes. Methods for preliminary qualitative phytochemical tests of the plant extracts are given below in the Tables 1 \& 2.

Table 1: Relationship of Angle of Repose, Carr's Index \&

\begin{tabular}{|c|c|c|c|c|}
\hline S.No. & $\begin{array}{l}\text { Phyto- } \\
\text { Constituents }\end{array}$ & Name of Tests & Procedure & Observation \\
\hline \multirow[t]{3}{*}{1.} & Alkaloids & Mayer's test & $2 \mathrm{ml}$ extract + few drops of $\mathrm{HCl}+$ Mayer's reagent & Cream Precipitation \\
\hline & & Hager's test & $2 \mathrm{ml}$ extract + few drops of $\mathrm{HCl}+$ Hager's reagent & Yellow Precipitation \\
\hline & & Wagner's test & $2 \mathrm{ml}$ extract + few drops of $\mathrm{HCl}+$ Wagner's reagent & Reddish brown color \\
\hline 2. & Carbohydrates & Molish test & $\begin{array}{l}2 \mathrm{ml} \text { extract }+2 \text { Drops of Molish reagent }+ \text { few drops of Conc. } \\
\text { H2SO4 }\end{array}$ & Violet or Reddish color \\
\hline 3. & $\begin{array}{l}\text { Reducing } \\
\text { sugars }\end{array}$ & Fehling's test & $1 \mathrm{ml}$ extract $+1 \mathrm{ml}$ Fehling Solution $(\mathrm{A}$ and $\mathrm{B})$ & $\begin{array}{l}\text { First a Yellow and then Brick } \\
\text { Red Precipitation }\end{array}$ \\
\hline \multirow[t]{2}{*}{4.} & \multirow[t]{2}{*}{ Flavonoids } & Alkaline reagent test & $2 \mathrm{ml}$ extract + few drops of $40 \% \mathrm{NaOH}$ solution & $\begin{array}{l}\text { Intense yellow color forms } \\
\text { which becomes colorless on } \\
\text { addition of dil. acid }\end{array}$ \\
\hline & & Lead acetate test & $2 \mathrm{ml}$ extract + few drops of Lead Acetate solution & Yellow precipitation \\
\hline 5. & Saponins & Foam test & $\begin{array}{l}2 \mathrm{ml} \text { extract }+4 \mathrm{ml} \text { distilled } \mathrm{H} 2 \mathrm{O} \\
\text { Mix well and shake vigorously }\end{array}$ & Foam formation \\
\hline 6. & Tannins & Braymer's test & $2 \mathrm{ml}$ extract $+2 \mathrm{ml} \mathrm{H} 2 \mathrm{O}+2-3$ drops of $5 \% \mathrm{FeCl} 3$ & Black green or bluish color \\
\hline
\end{tabular}
Hausner's Ratio with Flow Properties of Powder.

\begin{tabular}{|c|c|c|c|}
\hline $\begin{array}{c}\text { Angle of } \\
\text { Repose }\end{array}$ & Carr's Index & $\begin{array}{c}\text { Hausner's } \\
\text { Ratio }\end{array}$ & $\begin{array}{c}\text { Flow } \\
\text { Properties }\end{array}$ \\
\hline $25-30$ & $<10$ & $1.00-1.11$ & Excellent \\
\hline $31-35$ & $11-15$ & $1.12-1.18$ & Good \\
\hline $36-40$ & $16-20$ & $1.19-1.25$ & Fair \\
\hline $41-45$ & $21-25$ & $1.26-1.34$ & Passable \\
\hline $46-55$ & $26-31$ & $1.35-1.45$ & Poor \\
\hline $56-65$ & $32-37$ & $1.46-1.59$ & Very Poor \\
\hline$>66$ & $>38$ & $>1.60$ & Very Very Poor \\
\hline
\end{tabular}




\begin{tabular}{|c|c|c|c|c|}
\hline 7. & Steroids & Salkowski's test & $2 \mathrm{ml}$ extract $+2 \mathrm{ml}$ Chloroform $+2 \mathrm{ml}$ Conc. $\mathrm{H} 2 \mathrm{SO} 4$ & $\begin{array}{c}\text { Chloroform layer appears red } \\
\text { and acid layer shows greenish- } \\
\text { yellow fluorescence }\end{array}$ \\
\hline 8. & Proteins & Millon's test & $3 \mathrm{ml}$ extract $+5 \mathrm{ml}$ Millon's reagent & $\begin{array}{l}\text { White precipitate which turns } \\
\text { brick red on warming }\end{array}$ \\
\hline 9. & Glycosides & Keller Killiani's test & $\begin{array}{l}2 \mathrm{ml} \text { extract + Glacial acetic Acid + } 1 \text { drop of } 5 \% \mathrm{FeCl} 3+\text { Conc. } \\
\text { H2SO } 4\end{array}$ & $\begin{array}{c}\text { Reddish brown color appears } \\
\text { at the junction of } 2 \text { layers and } \\
\text { upper layer appears bluish } \\
\text { green }\end{array}$ \\
\hline \multirow{2}{*}{10.} & \multirow{2}{*}{ Phenols } & - & $2-3 \mathrm{ml}$ of extract + few drops of $5 \% \mathrm{FeCl} 3$ solution & Deep blue-black color \\
\hline & & & $2-3 \mathrm{ml}$ of extract + few drops of Lead Acetate solution & White precipitate \\
\hline 11. & Amino acids & Ninhydrin test & $\begin{array}{l}3 \mathrm{ml} \text { of extract }+3 \text { drops of } 5 \% \text { Ninhydrin solution } \\
\text { Keep in boiling water bath for } 10 \mathrm{~min} .\end{array}$ & Purple or bluish color appears \\
\hline 12. & Terpenoids & Copper Acetate test & $\begin{array}{c}2 \mathrm{ml} \text { extract dissolved in water }+3-4 \text { drops of Copper Acetate } \\
\text { solution }\end{array}$ & Emerald green color \\
\hline
\end{tabular}

\section{Determination of Heavy Metals (Lead and Cadmium)}

Method (Direct Calibration Method): Three reference solutions of the element being examined having different concentrations were prepared covering the range recommended by the instrument manufacturer. Separately the corresponding reagents were added for the test solution and the blank solution was prepared with the corresponding reagents. The absorbance of the blank solution and each reference solution were measured separately, and the readings were recorded. A calibration curve was prepared with the average value of 3 readings of each concentration on the ordinate and the corresponding concentration on the abscissa. A test solution of the substance being examined was prepared as specified in the monograph. The concentration was adjusted such that it falls within the concentration range of the reference solution. The absorbance was measured 3 times, and the readings were recorded and the average value was calculated. The mean value was interpolated on the calibration curve to determine the concentration of the element.

Preparation of Lead standard solution: Lead standard solutions were prepared from Stock solution (1000ppm Sisco Research Laboratories Pvt. Ltd. stock solution). Standard solutions of concentrations, 2, 4, 6, 8 and $10 \mathrm{ppm}$ were prepared. The absorption of standard solution measured at $217 \mathrm{~nm}$ using hallow cathode lamp as a light source \& air acetylene blue flame on Atomic absorption Spectrophometer.

Preparation of Cadmium standard solution: Cadmium standard solutions were prepared from Stock solution (1000ppm Sisco Research Laboratories Pvt. Ltd. stock solution). Standard solutions of concentrations $0.2,0.4,0.6,0.8$ and $1.0 \mathrm{ppm}$ was prepared. The absorption of standard solution measured at 228.8nm using hallow cathode lamp as a light source \& air acetylene blue flame on Atomic absorption Spectrophometer.

Preparation of Test solution: Weigh accurately about $0.5 \mathrm{~g}$ of the coarse powder of the substance being examined, transfer into a casparian flask, add $5-10 \mathrm{ml}$ of the mixture of nitric acid (HNO3) and perchloric acid (HCIO4) (4:1), add a small hopper on the flask- top, macerate overnight, heat to slake on the electric hot plate, keep somewhat-boiling, if brownish-black in color, add again a quantity of the above mixture, continuously heat till the solution becomes clear and transparent, then raise temperature, heat continuously to thick smoke, till white smoke disperse, the slaked solution becomes colorless and transparent or a little yellow, cool, transfer it into a $50 \mathrm{ml}$ volumetric flask, wash the container with $2 \%$ nitric acid solution $\left(\mathrm{HNO}_{3}\right)$, add the washing solution into the same volumetric flask and dilute with the same solvent to the volume, shake well. Prepare synchronously the reagent blank solution according to the above procedure.

Determination: Measure accurately $1 \mathrm{ml}$ of the test solution and its corresponding reagent blank solution respectively, add 1 $\mathrm{ml}$ of solution containing $1 \% \mathrm{NH}_{4} \mathrm{H}_{2} \mathrm{PO}_{4}$ and $0.2 \% \mathrm{Mg}\left(\mathrm{NO}_{3}\right)_{2}$, shake well, pipette accurately $10-20 \mu$ to determine the absorbance.

Sample analysis: The analysis of the digested samples were carried out using an Atomic Absorption Spectrophotometer (EC Electronics Corporation of India limited AAS Element AS AAS4141) for Lead and Cadmium. The instrumental conditions for Lead analysis are depicted in Table 3.

Table 3: Instrumental Conditions for Analysis of Lead and Cadmium.

\begin{tabular}{|c|c|c|}
\hline Parameters & Pb & Cd \\
\hline Wavelength (nm) & 217 & 228.8 \\
Slit width (nm) & 1.0 & 0.5 \\
Light Source & Hollow Cathode Lamp & Hollow Cathode Lamp \\
Flame type & Air $/ \mathrm{C} 2 \mathrm{H} 2$ & Air $/ \mathrm{C} 2 \mathrm{H} 2$ \\
Current & 10 & 3.5 \\
AAS Technique & Flame & Flame \\
\hline
\end{tabular}

\section{Results}

\section{Organoleptic Evaluation}

The observations for the organoleptic evaluation of three brands of Triphala Churna are reported in Table 4. 
Table 4: IResults for Organoleptic Evaluation of different brands of Triphala churna

\begin{tabular}{|c|c|c|c|c|}
\hline S.No. & PROPERTIES & BRAND A & BRAND B & BRAND C \\
\hline 1. & Appearance & Powder & Powder & Powder \\
\hline 2. & Color & Brown & Light Brown & $\begin{array}{c}\text { Yellowish } \\
\text { Brown }\end{array}$ \\
\hline 3. & Odor & Characteristic & Characteristic & Characteristic \\
\hline 4. & Taste & Salty and sour & $\begin{array}{c}\text { Salty and } \\
\text { sour }\end{array}$ & Bitter \\
\hline 5. & Texture & Fine Powder & $\begin{array}{c}\text { Moderately } \\
\text { Fine Powder }\end{array}$ & $\begin{array}{c}\text { Moderately } \\
\text { Fine Powder }\end{array}$ \\
\hline
\end{tabular}

\section{Pharmaceutical Evaluation}

The observations for the pharmaceutical evaluation of three brands of Triphala Churna are reported in Table 5.

Table 5: Results for Pharmaceutical Evaluation of different brands of Triphala churna.

\begin{tabular}{|c|c|c|c|c|}
\hline S.No. & PROPERTIES & BRAND A & BRAND B & BRAND C \\
\hline 1. & Bulk Density & 0.657 & 0.584 & 0.730 \\
\hline 2. & $\begin{array}{c}\text { Tapped } \\
\text { Density }\end{array}$ & 0.822 & 0.877 & 0.939 \\
\hline 3. & $\begin{array}{c}\text { Hausner's } \\
\text { Ratio }\end{array}$ & 1.25 & 1.50 & 1.28 \\
\hline 4. & Carr's Index & $20.07 \%$ & $33.40 \%$ & $22.26 \%$ \\
\hline 5. & $\begin{array}{c}\text { Angle of } \\
\text { Repose }\end{array}$ & $31.604^{\circ}$ & $46.505^{\circ}$ & $41.876^{\circ}$ \\
\hline
\end{tabular}

\section{Physico-Chemical Evaluation}

The observations for the physico-chemical evaluation of three brands of Triphala Churna are reported in Table 6.

Table 6: Results for Physico-chemical Evaluation of different brands of Triphala churna.

\begin{tabular}{|c|c|c|c|c|c|}
\hline S.No. & PROPERTIES & $\begin{array}{c}\text { BRAND } \\
\text { A }\end{array}$ & $\begin{array}{c}\text { BRAND } \\
\text { B }\end{array}$ & $\begin{array}{c}\text { BRAND } \\
\text { C }\end{array}$ & $\begin{array}{c}\text { STANDARD } \\
\text { (IP) }\end{array}$ \\
\hline 1. & Foreign Matter & Nil & Nil & Nil & NMT 3.0\% \\
\hline 2. & $\mathrm{pH}$ & 3.2 & 3.3 & 3.2 & - \\
\hline 3. & $\begin{array}{c}\text { Loss on } \\
\text { Drying/ } \\
\text { Moisture } \\
\text { Content }\end{array}$ & $11.86 \%$ & $11.73 \%$ & $10.07 \%$ & NMT $12.0 \%$ \\
\hline 4. & $\begin{array}{c}\text { Water Soluble } \\
\text { Extractive }\end{array}$ & $49.6 \%$ & $40.8 \%$ & $40.8 \%$ & NLT 35.0\% \\
\hline 5. & $\begin{array}{c}\text { Alcohol Soluble } \\
\text { Extractive }\end{array}$ & $28.0 \%$ & $29.6 \%$ & $26.4 \%$ & NLT 25.0\% \\
\hline 6. & $\begin{array}{c}\text { Loss on } \\
\text { Ignition }\end{array}$ & $97.06 \%$ & $95.89 \%$ & $97.07 \%$ & - \\
\hline 7. & Total Ash Value & $3.52 \%$ & $4.44 \%$ & $3.36 \%$ & NMT $8.0 \%$ \\
\hline 8. & $\begin{array}{c}\text { Acid Insoluble } \\
\text { Ash }\end{array}$ & $2.86 \%$ & $2.04 \%$ & $2.95 \%$ & NMT 3.0\% \\
\hline 9. & $\begin{array}{c}\text { Water Soluble } \\
\text { Ash }\end{array}$ & $5.96 \%$ & $6.31 \%$ & $5.85 \%$ & - \\
\hline
\end{tabular}

\section{Phytochemical Evaluation}

The observations for the phytochemical evaluation of three brands of Triphala Churna are reported in Table 7.

Table 7: Phytochemical Screening of Triphala Churna.

\begin{tabular}{|c|c|c|c|c|c|c|c|c|}
\hline \multirow[t]{2}{*}{ S. No. } & \multirow[t]{2}{*}{$\begin{array}{c}\text { PHYTO- } \\
\text { CONSTITUENT }\end{array}$} & \multirow[t]{2}{*}{ NAME OF TESTS } & \multicolumn{2}{|c|}{ BRAND A } & \multicolumn{2}{|c|}{ BRAND B } & \multicolumn{2}{|c|}{ BRAND C } \\
\hline & & & Aq. & Alco. & Aq. & Alco. & Aq. & Alco. \\
\hline \multirow{3}{*}{1.} & \multirow{3}{*}{ Alkaloids } & Hager's test & - & - & - & - & - & - \\
\hline & & Wagner's test & - & - & - & - & - & - \\
\hline & & Mayer's test & - & - & - & - & - & - \\
\hline 2. & Glycosides & Keller Killani's test & - & - & + & + & - & - \\
\hline 3. & Carbohydrates & Molisch's test & + & + & + & + & + & + \\
\hline \multirow{2}{*}{4.} & \multirow{2}{*}{ Proteins } & Biuret's test & - & - & - & - & - & - \\
\hline & & Millon's test & - & - & - & - & - & - \\
\hline 5. & Amino Acids & Ninhydrin's test & - & - & - & - & - & - \\
\hline 6. & Steroids & Salkowski's test & + & + & + & + & + & + \\
\hline \multirow[t]{2}{*}{7.} & \multirow[t]{2}{*}{ Flavonoids } & $\begin{array}{c}\text { Alkaline Reagent } \\
\text { test }\end{array}$ & + & + & + & + & + & + \\
\hline & & Lead acetate test & + & + & + & + & + & + \\
\hline 8. & Terpenoids & Copper Acetate test & - & - & - & - & - & - \\
\hline 9. & Tannins & Ferric Chloride test & + & + & + & + & + & + \\
\hline 10. & Saponins & Foam test & + & - & + & - & + & - \\
\hline \multirow[t]{2}{*}{11.} & \multirow{2}{*}{ Phenols } & Ferric Chloride test & + & + & + & + & + & + \\
\hline & & Lead Acetate test & + & + & + & + & + & + \\
\hline 12. & Ascorbic Acid & - & + & + & + & + & + & + \\
\hline
\end{tabular}




\section{Determination of Heavy Metals (Lead and Cadmium)}

The observations for the heavy metal determination of three brands of Triphala Churna are reported in Table 8.

Table 8: Heavy metal analysis of Triphala Churna.

\begin{tabular}{|c|c|c|c|c|c|}
\hline S.No. & PROPERTIES & BRAND A & BRAND B & $\begin{array}{c}\text { BRAND } \\
\text { C }\end{array}$ & $\begin{array}{c}\text { STANDARD } \\
\text { (API) }\end{array}$ \\
\hline a. & Lead & 2.897 & 3.542 & 3.567 & $10 \mathrm{ppm}$ \\
\hline b. & Cadmium & 0.232 & 0.135 & 0.227 & $0.3 \mathrm{ppm}$ \\
\hline
\end{tabular}

\section{Discussion}

Triphala churna of Brand A was of powder form of Brown color with a characteristic odor and salty-sour taste. This preparation had $\mathrm{pH}$ value of 3.2 , and Loss on drying value of $11.86 \% \mathrm{w} / \mathrm{w}$. Preparation had Alcohol soluble extractives and Water soluble extractives values of $28.0 \% \mathrm{w} / \mathrm{w}$ and $49.6 \% \mathrm{w} / \mathrm{w}$ respectively. The bulk density and tapped density of the powder were 0.657 and 0.822 respectively. The powder flow was fair-good as it had the Carr's Index of 20.07\% (Fair), Hausner's ratio of 1.25 (Fair) and Angle of repose of $31.604^{\circ}$ (Good). It had Total Ash value of $3.52 \% \mathrm{w} / \mathrm{w}$, and Acid insoluble ash and Water soluble ash value of $2.86 \% \mathrm{w} / \mathrm{w}$ and $5.96 \% \mathrm{w} / \mathrm{w}$ respectively. Loss on ignition was found $97.06 \% \mathrm{w} / \mathrm{w}$. The concentrations for heavy metals Lead and Cadmium were found to be 2.897 and 0.232 respectively which were within the prescribed limits. Phytochemical screening revealed the presence of Carbohydrates, Steroids, Flavonoids, Tannins, Phenols and Ascorbic acid in both the extracts and of Saponins in aqueous extract only.

Triphala churna of Brand B was of powder form of Light brown color with a characteristic odor and salty-sour taste. This preparation had $\mathrm{pH}$ value of 3.3 , and Loss on drying value of $11.73 \% \mathrm{w} / \mathrm{w}$. Preparation had Alcohol soluble extractives and Water soluble extractives values of $29.6 \% \mathrm{w} / \mathrm{w}$ and $40.8 \% \mathrm{w} / \mathrm{w}$ respectively. The bulk density and tapped density of the powder were 0.584 and 0.877 respectively. The powder flow was poor-very poor as it had the Carr's Index of $33.40 \%$ (Very poor), Hausner's ratio of 1.50 (Very poor) and Angle of repose of $46.505^{\circ}$ (Poor). It had Total Ash value of $4.44 \% \mathrm{w} / \mathrm{w}$, and Acid insoluble ash and Water soluble ash value of $2.04 \% \mathrm{w} / \mathrm{w}$ and $6.31 \% \mathrm{w} / \mathrm{w}$ respectively. Loss on ignition was found $95.89 \% \mathrm{w} / \mathrm{w}$. The concentrations for heavy metals Lead and Cadmium were found to be 3.542 and 0.135 respectively which were within the prescribed limits. Phytochemical screening revealed the presence of Glycosides, Carbohydrates, Steroids, Flavonoids, Tannins, Phenols and Ascorbic acid in both the extracts and of Saponins in aqueous extract only.

Triphala churna of Brand C was of powder form of Yellowish brown color with a characteristic odor and bitter taste. This preparation had $\mathrm{pH}$ value of 3.2 , and Loss on drying value of $10.07 \% \mathrm{w} / \mathrm{w}$. Preparation had Alcohol soluble extractives and Water soluble extractives values of $26.4 \% \mathrm{w} / \mathrm{w}$ and $40.8 \% \mathrm{w} / \mathrm{w}$ respectively. The bulk density and tapped density of the powder were 0.730 and 0.939 respectively. The powder flow was passable as it had the Carr's Index of $22.26 \%$ (Passable), Hausner's ratio of 1.28 (Passable) and Angle of repose of $41.876^{\circ}$ (Passable). It had
Total Ash value of 3.36\% w/w, and Acid insoluble ash and Water soluble ash value of $2.95 \% \mathrm{w} / \mathrm{w}$ and $5.85 \% \mathrm{w} / \mathrm{w}$ respectively. Loss on ignition was found $97.07 \% \mathrm{w} / \mathrm{w}$. The concentrations for heavy metals Lead and Cadmium were found to be 3.567 and 0.227 respectively which were within the prescribed limits. Phytochemical screening revealed the presence of Carbohydrates, Steroids, Flavonoids, Tannins, Phenols and Ascorbic acid in both the extracts and of Saponins in aqueous extract only.

\section{Conclusion}

Thus, all the parameters of three brands of Triphala Churna had approximately similar values and were compatible with the standard values mentioned in the Pharmacopoeias except that there was a considerable difference between the flow properties of the powder of all three brands. Hence, from the overall results it can be concluded that phytochemical and analytical evaluation of all the formulations should be done analytically on every batch so as to optimize the final product according to the Pharmacopoeial standards which probably has an impact on the therapeutic activity of the product. The results obtained from the study could be utilized as a reference for setting limits for the reference standards for the quality control and quality assurance of these drugs.

\section{Acknowledgement}

Author is thankful to his guide and co-guides for their encouragement towards research work. Also giving thanks and appreciates to Dr. H.S. Purohit, Professor and HOD and Dr. Gajanand Jat, Assistant professor, Department of Agricultural Chemistry and Soil Sciences, Rajasthan College of Agriculture, Udaipur, Rajasthan for their timely suggestions and for providing necessary facilities to carry out the research work.

\section{References}

1. Jarald EE (2007) Textbook of pharmacognosy and Phytochemistry. 1st ed. New Delhi (IN):CBS publication.

2. Pinjari EK, Patil HR, Navade JR, Chaudhari NB, DeshmukhTA (2017) Review on standardization of herbal drugs. SPER J Anal Drug Regul Aff 2(2):33-39.

3. Peterson CT, Denniston K, Chopra D (2017) Therapeutic Uses of Triphala in Ayurvedic Medicine. Journal of Alternative and Complementary Medicine 23(8):607-614.

4. Kumar NS, Nair AS, Nair AM, Murali M (2016) Pharmacological and therapeutic effects of triphala - A literature review. Journal of Pharmacognosy and Phytochemistry 5(3): 23-27.

5. Kokate CR, Purohit AP, Gokhale SB, Pharmacognosy (2010) In: Kokate CR, Purohit AP, Gokhale SB. (Kokate CR) Pharmacognosy .(45th ed), Vol. I, Nirali Prakashan. Pune, India.

6. Anonymous(2016). The Ayurvedic Pharmacopoeia of India Part 1. (1 $1^{\text {st }}$ edn), Vol. 9. Government of India, Ministry of AYUSH. Ghaziabad (IN): Pharmacopoeia Commission for Indian Medicine \& Homoeopathy.

7. Anonymous. WHO Guidelines for assessing quality of herbal medicines with reference to contaminants and residues (2007). Geneva (Switzerland): World Health Organization. Available from: http://apps. who.int/medicinedocs/documents/s14878e/s14878e.pdf

8. Khandelwal KR (2016) Practical Pharmacognosy- Techniques and Experiments. 26th ed. Pune (IN): Nirali Prakashan. 
9. Lohar DR (2011) Protocol for Testing Ayurvedic, Siddha \& Unani Medicines. Government of India, Department of AYUSH, Ministry of Health \& Family Welfare. Ghaziabad (IN): Pharmacopoeial Laboratory for Indian Medicines.

10. Anonymous. U.S. Pharmacopoeia-National Formulary (2015) [USP 39 NF 34]. Volume 1. Rockville, Md: United States Pharmacopoeial Convention, Inc.

11. Anonymous. The Indian Pharmacopoeia (2010), Vol. 1. Government of India, Ministry of Health and Family Welfare. Ghaziabad (IN): The Indian Pharmacopoeial Commission.

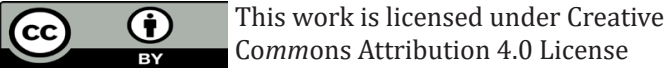

Submission Link: https://biomedres.us/submit-manuscript.php
12. Anonymous. Guidance Manual for Monographs Development of Herbs and Herbal products (2015) Government of India, Ministry of Health and Family Welfare. New Delhi (IN): Indian Pharmacopoeia Commission.

13. Gaud RS and Gupta GD (2008) Practical Physical Pharmacy. 1st ed. New Delhi (IN): CBS Publishers and Distributors.

$\begin{array}{ll}\text { BIOMEDICAL } & \text { Assets of Publishing with us } \\ \text { RESEARCHES } & \text { - Global archiving of articles } \\ & \text { - Immediate, unrestricted online access } \\ & \text { - Rigorous Peer Review Process } \\ \end{array}$

